\title{
Assessment of nitrogen content in buffalo manure and land application costs
}

\author{
Salvatore Faugno, ${ }^{1}$ Stefania Pindozzi, ${ }^{1}$ Roberta Infascelli, ${ }^{1}$ Collins Okello, ${ }^{1,2}$ \\ Maria Nicolina Ripa, ${ }^{3}$ Lorenzo Boccia ${ }^{1}$ \\ 'Department of Agricultural Engineering and Agronomy, University of Naples Federico II, Portici \\ (NA), Italy; ${ }^{2}$ Gulu University, Department of Biosystems Engineering, Uganda; \\ ${ }^{3}$ Department of Agriculture, Forestry and Energy, University of Tuscia, Viterbo, Italy
}

\begin{abstract}
Buffalo (Bubalus bubalis) livestock for mozzarella cheese production plays a fundamental role in the economy of southern Italy. European and Italian regulations consider nitrogen content in buffalo manure to be the same as that of cattle manure. This study aimed to assess whether this assumption is true. The first aim of the study was to assess nitrogen content in buffalo manure. Samples were taken from 35 farms to analyse nitrogen and phosphorous concentration in the manure. Analysis confirmed a lower nitrogen concentration (2\%) in buffalo manure. A secondary aim of the study was to evaluate whether manure application techniques that are apparently less suitable, e.g. splash plate spreader, could be feasible. The cost of different methods of land application of manure and their characteristics were evaluated on the basis of one operational cycle. Considering losses for volatilisation, and taking into account cost assessment, the immediate incorporation of buffalo manure (nitrogen content $2 \%$ ) is a suitable method of ammonia volatilisation. However, it is expensive and involves high fuel consumption in relation to the environmental benefit.
\end{abstract}

Correspondence: Lorenzo Boccia, Department of Agricultural Engineering and Agronomy, University of Naples Federico II, via Università 100, 80055 Portici (NA), Italy. Tel. +39.081.2539151. E-mail: lorenzo.boccia@unina.it

Key words: Bubalus bubalis, buffalo manure, manure management, spreading techniques, spreading costs.

Acknowledgements: this assessment of nutrient content in buffalo manure was funded by the Region of Campania under the project Actions for an integrated strategy for the management of some biomass produced in agriculture. This project is part of the region's Programme of assistance in scientific experimentation, information, research and consultancy in agriculture. The Region of Campania was not involved in the study design, data collection, analysis or interpretation, the writing of the report, or in the decision to submit the paper for publication.

Received for publication: 3 June 2012.

Accepted for publication: 29 August 2012.

(C) Copyright S. Faugno et al., 2012

Licensee PAGEPress, Italy

Journal of Agricultural Engineering 2012; XLIII:e13

doi:10.4081/jae.2012.e13

This article is distributed under the terms of the Creative Commons Attribution Noncommercial License (by-nc 3.0) which permits any noncommercial use, distribution, and reproduction in any medium, provided the original author(s) and source are credited.

\section{Introduction}

Buffalo livestock farming is typical of southern Italy, especially in the Region of Campania, with more than 250,000 heads of buffalo. Buffalo are bred to produce milk that is used to make mozzarella cheese. Until now, the nitrogen (N) and phosphorous (P) content of buffalo manure has been likened to that of dairy cattle, but empirical observations do not suggest any actual analogy. Over recent years, agronomic manure management has been common practice (Burton and Turner, 2003). This approach was set out in the 1991 Nitrates directive (European Commission, 1991) and has since then received the attention of the scientific community. To assess the potential agronomic use of buffalo manure, it would be more appropriate to consider a wide range of impact categories to determine at which handling stage the highest reduction in impact can be achieved (Prapaspongsa et al., 2010). Also, agronomic management is possible if it is reasonably cheap and compatible with agronomic schedules and with the conditions of soil workability (Mueller et al., 2003).

The compatibility of manure management according to agronomic schedules is very complex in the Province of Caserta because the typical cropping system on a livestock farm is based on corn silage as main crop and ryegrass (Lolium multiflorum) as winter intercrop (typically 3 cuttings from November to March followed by green manure of crop residues). In this context, it is not always easy to reconcile the optimal time frame with that of manure management and, although this is an important issue in many European regions, it is not always considered (Burton and Turner, 2003).

Furthermore, the energy costs of manure management also need to be considered, and a more pragmatic assessment of the different alternatives available for an integrated management is needed. The sustainability of an agronomic management approach should also be taken into account by considering the energy costs of spreading. It is important to consider greenhouse gases such as nitrous oxide $\left(\mathrm{N}_{2} \mathrm{O}\right)$ and methane $\left(\mathrm{CH}_{4}\right)$ that have global warming potential (GWPs) of 275 and 62, respectively, over a 20-year time span. GWPs are a measure of the relative radiative effect of a given substance compared to carbon dioxide $\left(\mathrm{CO}_{2}\right)$, integrated over a chosen time span (Houghton et al., 2001). Ammonia $\left(\mathrm{NH}_{3}\right)$ is also an interesting factor; this is not a greenhouse gas but it is one of the main causes of rain acidification. Webb et al. (2010) gave a full review of the importance of the problems of gaseous emissions from animal manure and a comparison of the options aiming to reduce emissions from the application of manure. On the other hand, some authors have presented an economic analysis to assess the cost:benefit ratio in spreading operations (McGechan and Wu, 1998; Huijsmans et al., $2003,2004)$. Their results are not always encouraging since the cost 
of spreading is not always offset by the agronomic value of nutrients applied, mainly because nitrogen losses of up to $70 \%$ can occur immediately after spreading (Huijsmans and De Mol, 1999; Sommer and Olesen, 2000; Huijsmans et al., 2003; Rohde and Etana, 2005).

Management of buffalo livestock manure in Campania is complex because of the large herds, often exceeding 100 per farm. Farms normally run to over 50 hectares but are scattered over a large geographical area. Therefore, spreading operations cover a large area. The number of heads per livestock herd is high in some areas; the ratio of heads per ha of usable agricultural surface exceeds 10 head/ha (Infascelli et al., 2010).

Infascelli et al. (2009) found a discrepancy between modelling of nitrate leaching and monitoring of the groundwater. Also, no spatial correlation between nitrogen production in livestock farms and nitrate concentration in groundwater was found (Infascelli et al., 2009). This strengthens the hypothesis that the agronomic use of manure is not economically feasible or not always feasible basing onunder an agronomic schedule. The first aim of the study was to characterise buffalo manure to understand the nitrogen content and to assess if it is comparable to that of cattle.

The only currently available data are from Campanile et al. (2010) who reported tests carried out mainly on individual animals. A secondary aim is to establish the relationship between the actual nitrogen input to the field and manure management costs by highlighting fuel consumption for spreading. Consequently, the goal is to assess whether the improvement of spreading operations, considering the actual nitrogen content, is economically viable. The final aim is to establish the fossil fuel consumption for spreading in order to identify the actual consequences of the management practices in terms of impact.

\section{Materials and methods}

\section{Buffalo manure}

To assess nitrogen content in buffalo manure, samples were taken from 35 farms in the Province of Caserta, southern Italy. The Province of Caserta, in the north-west of the Region of Campania, southern Italy, consists of a broad plain between the rivers Volturno and Garigliano. The climatic conditions and soil fertility guarantee excellent conditions for agriculture and livestock farming. The 35 selected farms represent typical livestock farms in the Caserta area in terms of management and organisation. Figure 1 shows the geographical distribution of the farms sampled in the study area. Most of the farms are located in a restricted area characterised by a large number of heads of buffalo (approx. $170,000)$ and a total agricultural area of approximately 100,000 ha.

Most of the farms sampled have only one storage tank to take the manure from both the milking and dry buffalo. This is typical of the farms in the region. Nevertheless, samples were also taken from farms that have different manure storage systems. Samples were collected from manure storage tanks rather than directly from the animal excretion because the concentration in storage tanks was considered to be more representative (Peters et al., 2003; Redding et al., 2007). Manure sampling was carried out according to the procedure described by Peters et al. (2003). In order to ensure homogenisation of manure in the storage tank before sampling, the manure underwent mechanical mixing for approximately one hour. However, not all farms were equipped with a mechanical mixer; on these farms, samples were taken from different parts of the tank, and manually homogenised and test samples were then taken. Liquid fractions were sampled from the tank using Coliwasa Waste Samplers (Peters et al., 2003). The solid samples

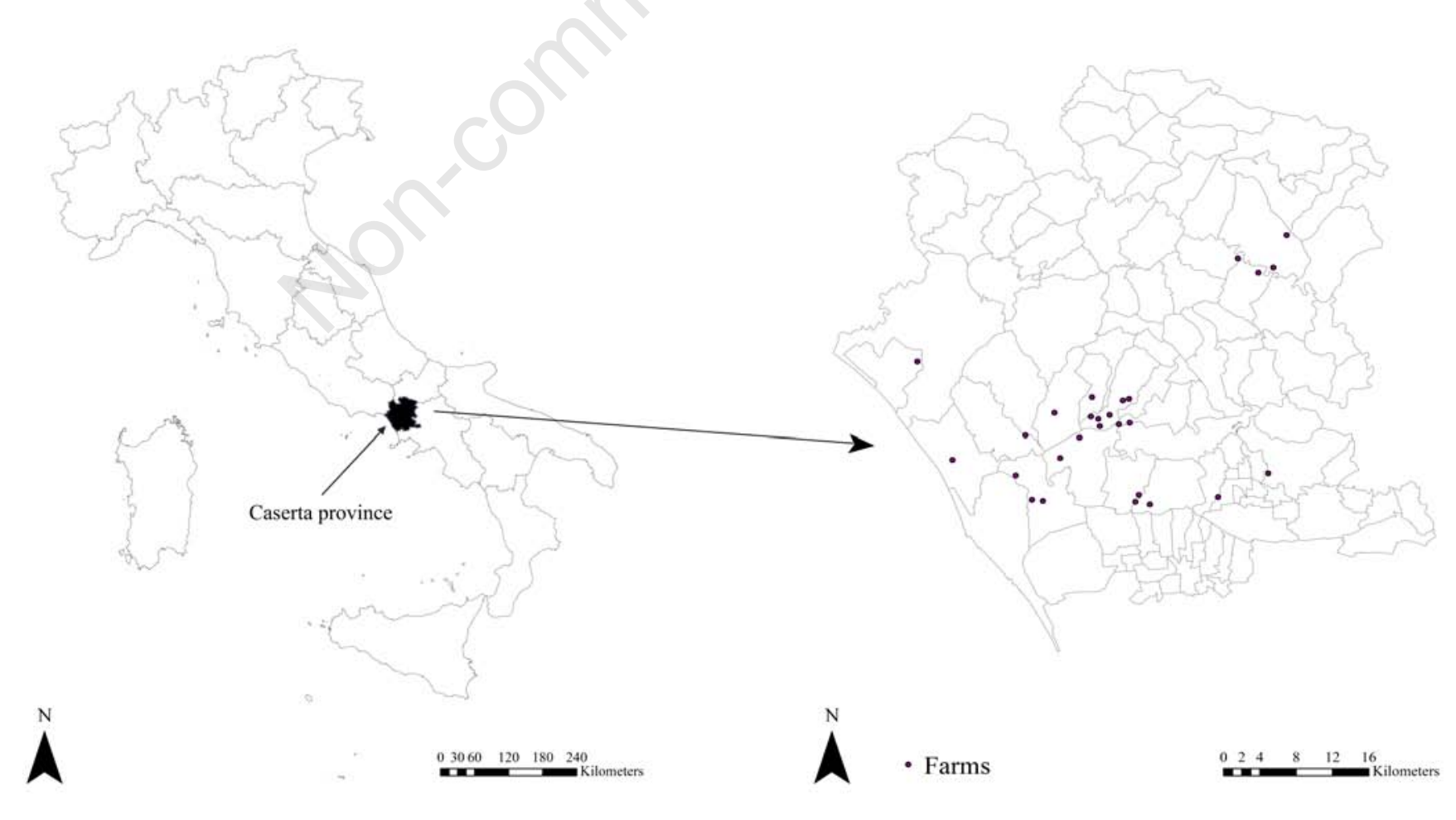

Figure 1. Farm locations and sampling in the province of Caserta. 
were also collected from different parts around the manure pile and were mixed using a shovel. Sub-samples were taken from the homogeneous mixture by a quartering method. Each sample was collected into a clean plastic container and was transported in a portable cooler box to the laboratory for analysis. Analysis was repeated for 20 of the 35 farms, resulting in 55 samples, from March to November 2009.

Dry Matter was measured using a muffle following the method described by Wolf et al. (1997). Total nitrogen was determined by the Kjeldahl method, after acidification with $\mathrm{H}_{2} \mathrm{SO}_{4}$ and mineralisation of the sample. Manure was analysed for Total Kjeldahl N following the 7A2 method (Rayment and Higginson, 1992). $\mathrm{PO}_{4}{ }^{3-}$ was measured using the PhosVer ${ }^{\circledR} 3$ reagent (Hach Co., Loveland, CO, USA). Concentration of orthophosphate was estimated from the absorbance of the sample measured at $890 \mathrm{~nm}$ using a DR2000 spectrophotometer (Hach Co.). Ammonia nitrogen and nitrates were determined by a colorimetric method with Hach reagents, after filtration with activated carbon and dilution (Peters et al., 2003).

The different samples were classified as milking, dry or mix depending on the tanks from which they were taken. The milking samples were taken from manure storage tank of milking buffalo that are fed a diet that is richer in protein, while the dry samples were from the sheds of dry buffalo that are fed a diet containing higher fibre with lower protein content. The mix samples were from the storage tank of manure taken from the sheds of both dry and milking buffalo. The average value $(\mu)$, the variance $\left(\sigma^{2}\right)$, the standard deviation $(\sigma)$ and the coefficient of variation of the measured parameters were calculated on a spreadsheet.

\section{Manure spreading management}

In this study, we compared the energy requirements of the splash plate spreader for surface spreading, and for the trailing foot for the immediate incorporation of manure into the soil. The energy require- ments of the two techniques were then compared with that of a tractordrawn mineral fertiliser spreader. For surface spreading, some authors reported nitrogen losses from volatilisation of $68 \%$ of total ammonia nitrogen (TAN) on arable land and 77\% on grassland (Huijsmans et al., $2001,2003)$. These nitrogen losses vary appreciably according to some external factors, such as temperature and radiation, hour of application, type of soil, and presence of crops, etc. (Webb et al., 2010). We assumed there would be less conservative nitrogen losses from volatilisation of $50 \%$ of surface spreading calculated by total ammoniacal nitrogen (TAN) content of the manure. Nitrogen losses from volatilisation are lower using the immediate incorporation technique (Webb et al., 2010). With this method, nitrogen losses in the range of $17 \%$ can be achieved on arable land (Huijsmans et al., 2003). Furthermore, immediate incorporation assures reduced $\mathrm{P}$ losses by runoff (Osei et al., 2003; Redding et al., 2007).

In this study, we considered two different operational systems according to Gaakeer: a) an $85 \mathrm{~kW}$ tractor either pulling a $10 \mathrm{~m}^{3}$ spreader tank with splash plate or carrying a $1.5 \mathrm{t}$ mineral fertiliser spreader; and b) a $100 \mathrm{~kW}$ tractor pulling a $10 \mathrm{~m}^{3}$ spreader tank with a trailing foot for immediate incorporation.

The financial investment in cost of tractors, tank trailers and injectors was estimated by considering prices reported in the directory of farm machinery (m\&ma, 2004), updated in 2011, according to the guidelines of the Italian Institute of Statistics (ISTAT, 2011). Operating costs were evaluated according to the guidelines set out on the web Macgest database. The main parameters are reported in Table 1.

To calculate operating costs, we considered that the value of the tractor, tank trailer and spreader depreciates over ten years. The interest rate was assumed to be $6.5 \%$, the residual value to be $10 \%$ of the replacement cost, and the cost of insurance to be $0.8 \%$ of the value at half-life. The machinery repair and operating costs were assumed to be $50 \%$ and $25 \%$ of the cost of a new tractor, respectively. Maintenance

Table 1. Assessment of cost per hour.

\begin{tabular}{|c|c|c|c|c|c|c|c|c|c|}
\hline & $\begin{array}{l}\text { Cost } \\
(€)\end{array}$ & $\begin{array}{l}\text { Annual } \\
\text { use } \\
\text { (h) }\end{array}$ & $\begin{array}{c}\text { Annual } \\
\text { depreciation } \\
(€ / h)\end{array}$ & $\begin{array}{l}\text { Insurance } \\
\qquad(€ / h)\end{array}$ & $\begin{array}{l}\text { Machinery } \\
\text { storage } \\
(€ / h)\end{array}$ & $\begin{array}{c}\text { General } \\
\text { costs } \\
(€ / h)\end{array}$ & $\begin{array}{l}\text { Self-repair } \\
\text { costs } \\
(€ / \mathrm{h})\end{array}$ & $\begin{array}{l}\text { Outside } \\
\text { repair costs } \\
(€ / h)\end{array}$ & $\begin{array}{c}\text { Cost per h } \\
\text { (bare rental) } \\
(€ / h)\end{array}$ \\
\hline $85 \mathrm{~kW}$ tractor & 54,000 & 1000 & 7.51 & 0.24 & 0.06 & 0.32 & 1.18 & 2.70 & 12.01 \\
\hline $100 \mathrm{~kW}$ tractor & 61,000 & 1000 & 8.49 & 0.27 & 0.06 & 0.37 & 1.18 & 3.05 & 13.42 \\
\hline $\begin{array}{l}10 \mathrm{~m}^{3} \text { spreader tank } \\
\text { with splash plate spreader }\end{array}$ & 27,000 & 500 & 7.51 & 0.24 & 0.1 & 0.32 & 1.77 & 2.25 & 12.19 \\
\hline $\begin{array}{l}10 \mathrm{~m}^{3} \text { spreader tank } \\
\text { with trailing foot }\end{array}$ & 32,500 & 500 & 9.04 & 0.29 & 0.10 & 0.39 & 1.77 & 2.71 & 14.30 \\
\hline $\begin{array}{l}\text { Mineral fertiliser } \\
\text { spreader } 1500 \mathrm{~kg}\end{array}$ & 7500 & 100 & 10.43 & 0.33 & 0.24 & 0.45 & 1.77 & 0.75 & 13.97 \\
\hline
\end{tabular}

Table 2. Fuel consumption of a tractor with spreader tank in different operating conditions.

\begin{tabular}{|c|c|c|c|c|c|c|c|c|c|c|}
\hline & $\begin{array}{l}\text { Tare } \\
(\mathrm{kg})\end{array}$ & $\begin{array}{c}\mathrm{Cr} \\
\text { Coefficient } \\
\text { of rolling } \\
\text { resistance } \\
(-)\end{array}$ & $\begin{array}{l}\text { Pulling } \\
\text { force } \\
(\mathrm{N})\end{array}$ & $\begin{array}{l}\text { Speed } \\
(\mathrm{m} / \mathrm{s})\end{array}$ & $\begin{array}{c}\text { Drawbar } \\
\text { power } \\
\text { (kW) }\end{array}$ & $\begin{array}{l}\eta g \text { Tractive } \\
\text { efficiency } \\
(-)\end{array}$ & $\begin{array}{l}\text { Power } \\
\text { applied } \\
\text { (kW) }\end{array}$ & $\begin{array}{l}\text { Specific fuel } \\
\text { consumption } \\
(\mathrm{g} / \mathrm{kWh})\end{array}$ & $\begin{array}{l}\text { Consumption } \\
\text { per h } \\
(\mathrm{L} / \mathrm{h})\end{array}$ & $\begin{array}{l}\text { Consumption } \\
\text { per km } \\
\text { (L/km) }\end{array}$ \\
\hline Full load on dirt track & 15,000 & 0.03 & 4414.5 & 5.5 & 24.3 & 0.6 & 40.5 & 250 & 10.1 & 0.51 \\
\hline Unladed on dirt track & 5000 & 0.03 & 1471.5 & 10 & 14.7 & 0.6 & 24.5 & 250 & 6.1 & 0.17 \\
\hline $\begin{array}{l}\text { Full load in field with } \\
\text { splash plate spreader }\end{array}$ & 15,000 & 0.1 & 1471.5 & 3 & 44.1 & 0.6 & 73.6 & 250 & 18.4 & 1.70 \\
\hline $\begin{array}{l}\text { Full load in field } \\
\text { with trailing foot }\end{array}$ & 15,000 & 0.1 & 29,715 & 1.5 & 44.6 & 0.6 & 74.3 & 250 & 18.6 & 3.44 \\
\hline Unloaded in field & 5000 & 0.1 & 4905 & 3 & 14.7 & 0.6 & 24.5 & 250 & 6.1 & 0.57 \\
\hline
\end{tabular}


labour costs were assumed to be $11.8 € / \mathrm{h}$, given that the cost for skilled labour is assumed to be $11.8 € / \mathrm{h}$ according to the average pay scales in southern Italy. This cost was appreciably less than the $14 € / \mathrm{h}$ assessed by Huijsmans et al. (2004) in other European Regions. Table 2 shows fuel consumption obtained by considering the requirements of the different working conditions.

The manure application rate was assumed to be $25 \mathrm{~m}^{3} / \mathrm{ha}$ according to Huijsmans et al. (2004). Considering a splash plate spreader with a net working width of $8 \mathrm{~m}$ (Huijsmans et al., 2001), the tractor needs to travel $500 \mathrm{~m}$ to spread the contents of a $10 \mathrm{~m}^{3}$ tanker in the field. We assumed an additional trip of $250 \mathrm{~m}$ from the field to the road. Therefore, spreading involves a round trip of $750 \mathrm{~m}$ characterised by the fully loaded tank in one phase and an empty tank in the other. Considering the same application rate of $25 \mathrm{~m}^{3} / \mathrm{ha}$ for immediate incorporation, and the networking width of $4 \mathrm{~m}$, a tractor must travel $1000 \mathrm{~m}$ to spread the contents of a $10 \mathrm{~m}^{3}$ tanker in the field plus $250 \mathrm{~m}$ to rejoin the road. Therefore, spreading using immediate incorporation entails a round trip of $1250 \mathrm{~m}$. It was assumed that the manure storage tank is located $2000 \mathrm{~m}$ away from the spreading area. This corresponds to a farm typical of the area studied, characterised by several small plots totalling approximately 50 ha connected by unpaved rural roads.

In assessing the actual field conditions, we considered a 50 ha farm, a cropping system based on corn silage (Zea mays) as main crop, and ryegrass (Lolium multiflorum) as winter intercrop, and nitrogen requirements of 20 t/year. These nitrogen requirements are in accordance with the Regional Fertilization Plan (Region of Campania, 2011) that recommends nitrogen requirements of $150 \mathrm{~kg} / \mathrm{ha}$ and $250 \mathrm{~kg} / \mathrm{ha}$ for ryegrass and corn silage, respectively. Two scenarios were assessed; the first was that $40 \%$ of the nitrogen is from manure and the other that all the nitrogen is from a chemical source. The cost of urea in 2011 was $1 €$ per kilo of nitrogen.

Calculations were made on the basis of a fertiliser spreader of $15 \mathrm{~m}$ effective width, used to spread urea or mineral fertiliser, and spreading $1500 \mathrm{~kg}$ of fertiliser containing $750 \mathrm{~kg}$ of nitrogen in one trip. As a result, it is possible to apply fertiliser over $7.5 \mathrm{ha}$, at a rate of $100 \mathrm{~kg}$ of nitrogen per ha, in one cycle. With these assumptions, we found that a fertilising cycle would involve a round trip of $5 \mathrm{~km}$ under the conditions reported in Table 3.

\section{Results}

\section{Buffalo manure}

Figures 2 to 4 summarise monthly results for nutrient content in the different storage tanks.

The average values and statistical data are reported in Table 4 .

Trends in monthly rainfall and mean rainfall values have an impact on the dilution of the manure samples and were, therefore, recorded by five weather stations in the study area (Table 5).

The ratio between ammonia nitrogen and total nitrogen is reported in Table 6; these were between 0.47 and 0.13 during the periods with the highest and the lowest rainfall, respectively.

The mean value of nitrogen content is $1950 \mathrm{mg} / \mathrm{L}$, i.e. $2 \mathrm{~kg}$ per $\mathrm{m}^{3}$ of manure (Table 7). Mean values of the two nutrients investigated are reported in the Table 7 .

\section{Spreading management}

Results of the study showed that the fuel consumption for spreading $10 \mathrm{~m}^{3}$ is 2.35 litres when using a splash plate spreader. The effective operation time is approximately $13.5 \mathrm{~min}$. When the time for loading and stoppages are considered, a complete cycle takes $21 \mathrm{~min}$ and costs $24.2 € / \mathrm{h}$. For immediate incorporation of $10 \mathrm{~m}^{3}$, fuel consumption is

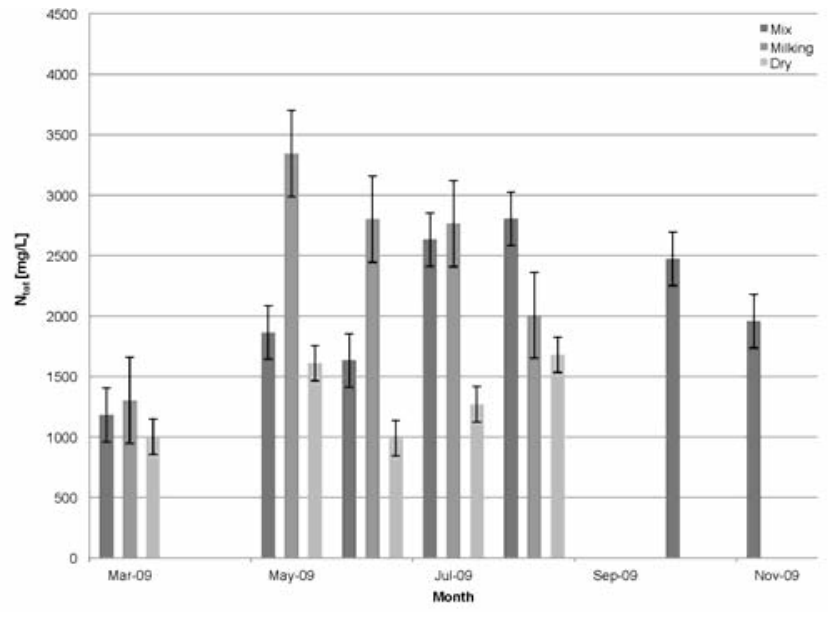

Figure 2. Average total nitrogen monthly concentration in the different storage tanks.

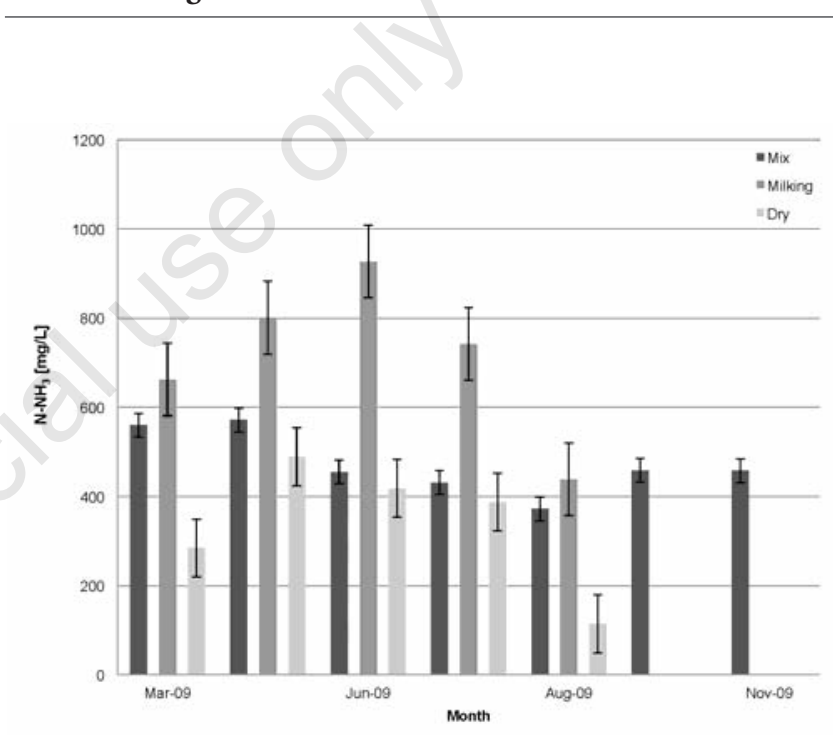

Figure 3. Average monthly ammoniacal nitrogen concentration in the different storage tanks.

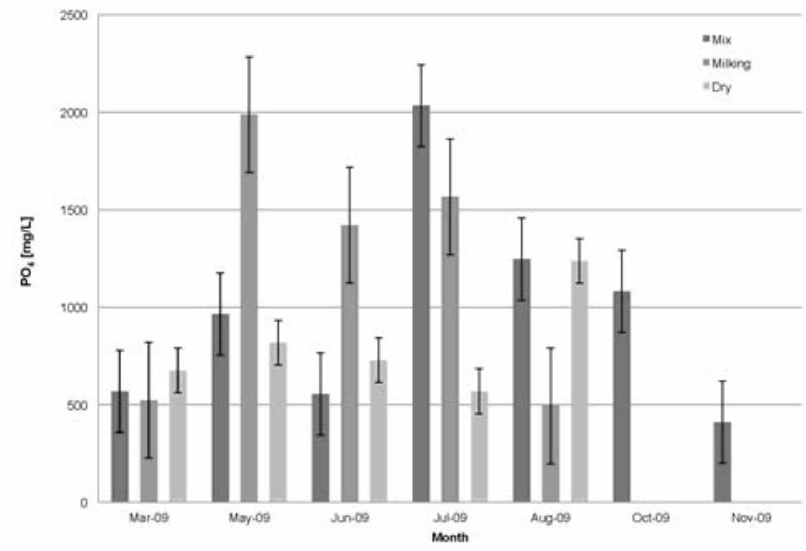

Figure 4. Average orthophosphate concentration in the different storage tanks. 
4.93 litres, the effective operative time is $22 \mathrm{~min}$, the total operative time, considering loading and stoppages, is approximately $29.4 \mathrm{~min}$ and costs $39.52 € / \mathrm{h}$. while the effective working time was $22 \mathrm{~min}$.

A complete cycle of chemical fertilising requires approximately 60 min with an N content of $750 \mathrm{~kg}$. Diesel fuel consumption for this cycle was 5.07 litres and total cost was $25.98 € / \mathrm{h}$. Table 8 shows the total cost for each application method.

For manure $\mathrm{N}$ content, a tank of $10 \mathrm{~m}^{3}$ carries approximately $20 \mathrm{~kg}$ of total nitrogen, $5 \mathrm{~kg}$ of which are ammoniacal nitrogen. In the case of manure application with a splash plate spreader, considering losses for ammonia volatilisation, effective $\mathrm{N}$ uptake in the soil is approximately $17.5 \mathrm{~kg}$ per cycle. $0 \mathrm{n}$ the other hand, the contribution of nitrogen to the soil with the immediate incorporation of manure, considering losses for ammonia volatilisation, is equal to approximately $19 \mathrm{~kg}$ of nitrogen per cycle. However, the fuel consumption, in this last case, increases to 4.94 litres.

To compare the effectiveness of manure application with chemical fertilisation, we considered the same soil nitrogen uptake for each method. The cost of chemical fertilisation with effective $\mathrm{N}$-uptake of $17.5 \mathrm{~kg}$ (i.e. the N-uptake with (splash plate spreader), was approximately $18.5 €$, consuming approximately 0.12 litres of diesel fuel. The cost of chemical fertilisation with effective $\mathrm{N}$-uptake of $19 \mathrm{~kg}$ (i.e. the $\mathrm{N}$-uptake with immediate incorporation) was approximately $20.05 €$, consuming 0.13 litres of diesel fuel.

\section{Discussion}

The mean value of nitrogen content of buffalo manure was found to be $1950 \mathrm{mg} / \mathrm{L}$. This is lower than that reported in literature for cattle: range $2000-7000 \mathrm{mg} / \mathrm{L}$ and $4200-8100 \mathrm{mg} / \mathrm{L}$ for liquid and solid manure, respectively (Burton and Turner, 2003). However, all legislation and calculations for the agronomic use of buffalo manure in the Region of Campania awere formulated on the basis of the value of nitrogen content of cattle manure. Nitrogen content in manure storage tanks of milking buffalo is higher than nitrogen content in tanks of dry herds. This is probably explained by the difference in feeding regimes which is characterised by more protein for milking buffalo compared to more fibre for dry herds. Results show ammonia nitrogen content $\left(0.6 \mathrm{~kg} / \mathrm{m}^{3}\right)$ to be $1-4.9 \mathrm{~kg} / \mathrm{m}^{3}$ lower than that reported in literature (Burton and Turner, 2003). There is a $30 \%$ difference in variance and standard deviation of nitrogen concentration between samples but these are consistent with the values reported by Campanile et al. (2010). Such variability could be explained by the variation in feeding regimes, exposure of the field to rain water, and the high level of rainfall in 2009, especially in April, May and June.

Final results show nitrogen content to be lower in buffalo manure than in cattle manure ( $2 \%$ buffalo manure, $3 \%$ cattle manure), even though national legislation has been based on statistics for cattle

Table 3. Fuel consumption of a tractor with fertiliser in different operating conditions.

\begin{tabular}{|c|c|c|c|c|c|c|c|c|c|c|}
\hline & $\begin{array}{l}\text { Speed } \\
(\mathrm{m} / \mathrm{s})\end{array}$ & $\begin{array}{l}\text { Power to } \\
\text { fertiliser } \\
\text { (PTO) } \\
\text { (kW) }\end{array}$ & $\begin{array}{l}\text { Tare } \\
\text { (kg) }\end{array}$ & $\begin{array}{c}\mathrm{Cr} \\
\text { Coefficient } \\
\text { of rolling } \\
\text { resistance } \\
(-)\end{array}$ & $\begin{array}{l}\text { Axle } \\
\text { power } \\
(\mathrm{kW})\end{array}$ & $\begin{array}{c}\eta g \\
\text { efficiency } \\
(-)\end{array}$ & $\begin{array}{l}\text { Engine } \\
\text { power } \\
(\mathrm{kW})\end{array}$ & $\begin{array}{c}\text { Specific C } \\
\text { fuel } \\
\text { consumption } \\
\text { (g/kWh) }\end{array}$ & $\begin{array}{l}\text { Consumption } \\
\text { per h } \\
\quad(\mathrm{L} / \mathrm{h})\end{array}$ & $\begin{array}{c}\text { Consumption } \\
\text { per km } \\
(\mathrm{L} / \mathrm{km})\end{array}$ \\
\hline Full load on dirt track & 5.5 & 0 & 8000 & 0.03 & 12.9 & 0.9 & 14.4 & 250 & 3.60 & 0.18 \\
\hline Unloaded on dirt track & 10 & 0 & 6500 & 0.03 & 19.1 & 0.9 & 21.3 & 250 & 5.31 & 0.15 \\
\hline Full load in field & 3 & 10 & 8000 & 0.1 & 23.5 & 0.9 & 37.3 & 250 & 9.32 & 0.86 \\
\hline Unloaded in field & 3 & 0 & 6500 & 0.1 & 19.1 & 0.9 & 21.3 & 250 & 5.31 & 0.45 \\
\hline
\end{tabular}

PTO, power take off; Cr, coefficient of rolling resistance.

Table 4. Measured nutrient concentration in storage tanks, mean $(\mu)$ variance $\left(\sigma^{2}\right)$, standard deviation $(\sigma)$ and coefficient of variation.

\begin{tabular}{lccccccccc} 
& & N total & & & N-NH & & & & $\mathrm{PO}_{4}$ \\
& Milking & Dry & Mix & Millking & Dry & Mix & Millking & Dry & Mix \\
$\mu(\mathrm{mg} / \mathrm{L})$ & 2444 & 1310 & 2078 & 714 & 339 & 472 & 1199 & 807 & 981 \\
$\sigma^{2}$ & 633,194 & 106,716 & 293,218 & 26,479 & 16,957 & 4267 & 351,804 & 52,893 & 266,268 \\
\hline$\sigma$ & 796 & 327 & 585 & 182 & 146 & 71 & 663 & 257 & 557 \\
$\mathrm{CV}(\%)$ & $33 \%$ & $25 \%$ & $28 \%$ & $25 \%$ & $43 \%$ & $15 \%$ & $55 \%$ & $32 \%$ & $57 \%$ \\
\hline
\end{tabular}

CV, coefficient of variation; $\mathrm{N}$, nitrogen; $\mathrm{N}-\mathrm{NH}_{3}$, ammoniacal nitrogen; $\mathrm{PO}_{4}$, phosphate.

Table 5. Average monthly rainfall at 5 weather stations in 2009.

\begin{tabular}{lcccccccccccc} 
Weather station & Jan & Feb & March & April & May & June & July & Aug & Sep & Oct & Nov & Dec \\
Alife & 205.5 & 42.9 & 177.6 & 75.2 & 44.9 & 122.5 & 31.2 & 4.1 & 40.7 & 41.8 & 135.4 & 120.2 \\
Castel Morrone & 344.8 & 54.4 & 239.6 & 114.4 & 78.8 & 130.4 & 10.8 & 22.8 & 68 & 169.4 & 231.8 & 154.4 \\
\hline Presenzano & 286.4 & 54.9 & 167.8 & 83 & 37.6 & 120.4 & 10.2 & 11.7 & 71.2 & 43.6 & 163.5 & 206.1 \\
Sessa Aurunca & 248 & 47.6 & 149.7 & 85.9 & 37 & 113.2 & 20.2 & 0 & 63.7 & 59.9 & 182.6 & 221.2 \\
\hline Vitulazio & 246.6 & 35 & 161.8 & 97.4 & 63.4 & 165.2 & 8.6 & 0 & 75 & 74.8 & 205.8 & 162.8 \\
\hline
\end{tabular}


Table 7. Nutrient mean $(\mu)$, variance $\left(\sigma^{2}\right)$, standard deviation $(\sigma)$ and coefficient of variation in buffalo manure.

\begin{tabular}{lcccc} 
Nutrient & \multicolumn{2}{c}{ Statistical parameters } & CV (\%) \\
& $\mu(\mathrm{mg} / \mathrm{L})$ & $\sigma^{2}$ & 579 & 30 \\
$\mathrm{~N}$ tot & 1960 & 334,717 & 190 & 37 \\
$\mathrm{~N}-\mathrm{NH}_{3}$ & 508 & 36,241 & 197 & 20 \\
\hline $\mathrm{PO}_{4}$ & 996 & 38,696 & & \\
\hline
\end{tabular}

$\mathrm{N}$, nitrogen; $\mathrm{N}-\mathrm{NH}_{3}$, ammoniacal nitrogen; $\mathrm{PO}_{4}$, phosphate; $\mathrm{CV}$, coefficient of variation.

Table 8. Time and cost of manure application with two different methods, and of spreading chemical fertiliser.

\begin{tabular}{|c|c|c|c|c|c|c|c|c|}
\hline \multirow{2}{*}{$\begin{array}{l}\text { Type of fertiliser } \\
\text { /application method }\end{array}$} & \multirow{2}{*}{$\begin{array}{l}\text { Time } \\
\text { per cycle } \\
\text { (min) }\end{array}$} & \multirow{2}{*}{$\begin{array}{l}\text { Fuel } \\
\text { consumption } \\
\text { (L) }\end{array}$} & \multirow[b]{2}{*}{$\begin{array}{l}\text { Tractor } \\
\text { rental }\end{array}$} & \multicolumn{3}{|c|}{ Cost (€/cycle) } & \multirow[b]{2}{*}{ Fertiliser } & \multirow[b]{2}{*}{ Total } \\
\hline & & & & Implement & Labour & $\begin{array}{l}\text { Fuel } \\
\text { cost }\end{array}$ & & \\
\hline $\begin{array}{l}\text { Manure surface spreading } \\
\left(10 \mathrm{~m}^{3}, 0.4 \text { ha }\right)\end{array}$ & 21.00 & 2.35 & 4.20 & 4.27 & 4.14 & 1.53 & 0 & 14.14 \\
\hline $\begin{array}{l}\text { Manure immediate incorporation } \\
\left(10 \mathrm{~m}^{3}, 0.4 \mathrm{ha}\right)\end{array}$ & 29.50 & 4.93 & 6.60 & 7.03 & 5.80 & 3.21 & 0 & 22.64 \\
\hline $\begin{array}{l}\text { Chemical fertiliser surface spreading } \\
\text { (750 kg N, } 7.5 \mathrm{ha})\end{array}$ & 60 & 5.07 & 12.01 & 13.97 & 11.8 & 3.30 & 750 & 791.08 \\
\hline
\end{tabular}

manure. However, recent legislation in some Italian regions, such as Campania and the Emilia Romagna, consider lower amounts of nitrogen for buffalo. The lower nitrogen content in buffalo manure confirms the experience of local farmers; they have seen that buffalo manure has a lower fertilising power than cattle manure. This lower nitrogen content is explained by the reduced diet given to buffalo and by assessments made in 2010 by Campanile et al. based on buffalo physiology. Results from territorial studies (Infascelli et al., 2010) in the Caserta area on the low nitrate pollution in groundwater in relation to the number of animals in that area, agree with a lower nutrient content in buffalo manure. The ratio between ammonia nitrogen and total nitrogen is lower in summer (Table 6). This is linked to the ammonia losses by volatilisation from tanks during the hotter months of the year. According to these results, nitrogen content (equal to $2 \%$ in a spreader tank) must be taken into account when calculating spreading costs for buffalo manure.

\section{Conclusions}

Results show that there is lower nutrient content in buffalo manure than in cattle manure. This agrees with findings of Campanile et al. (2010). Immediate incorporation is the most environmentally sustainable manure application technique when ammonia volatilisation is considered, but it is the most expensive (approx.1.19 €/kg of nitrogen per field). It also requires longer lead-time, mainly in the two pre-sowing periods; pre-sowing periods are extremely short in southern Italy. Maize should be sown as soon as it is possible to work the field after the winter rains. This is almost in contrast with the frequent and lengthy spreading that has to be carried out to empty the storage tanks after winter. Fertilising before sowing ryegrass, at the end of summer, is more appropriate in years with very heavy rain. Also, McGechan and Wu (1998) and Huijmans et al. (2004) reported similar findings in terms of field application cost. However, if fuel requirements are considered, withfor the immediate incorporation method, approximately 2.5 litres of extra fuel per cycle are needed to reduce ammonia in the environment by $2.5 \mathrm{~kg}$. It could be interesting to make a life cycle assessment to evaluate the ecological benefits of these practices.
The of findings of this study are not in complete agreement with those of Osei et al. (2003) who concluded, especially referring with respect to $\mathrm{P}$ losses, that manure incorporation would be the best management practice with acceptable costs to producers. Adding fuel requirements and application time to these costs may provide different results. With regard to energy resources and the environment, the splash plate spreader could be the preferred option, even if there are high ammonia losses for volatilisation, with the advantages of a much quicker operational time. In conclusion, use of a system that reduces dilution in buffalo manure on the farm appears to be essential. Furthermore, this study indicates the need to consider all factors having a significant impact on the decision as to the best manure management option to adopt. Local conditions, and also technological options such as drying by exploiting the excess heat in the co-generators, should also be taken into account.

\section{References}

Burton C.H., Turner C. 2003. Manure management - treatment strategies for sustainable agriculture, 2nd ed. Wrest Park-Silsoe (Silsoe Research Institute), Bedford, UK.

Campania Region. 2011. Guida alla concimazione - versione 2011. [In Italian]. Available from: http://www.agricoltura.regione. campania. it/concimazione/guida.htm

Campanile G., Neglia G., Vecchio D., Di Palo R., Gasparini B., Zicarelli L. 2010. Protein nutrition and nitrogen balance in buffalo cows. CAB Rev. Perspect. Agric. Vet. Sci. Nutr. Nat. Res. 5:1-8.

European Commission. 1991. 'Nitrates' directive, 91/676/EEC. In: Official Journal L 375, 31/12/1991, pp. 0001-0008.

Gaakeer W.A. 1998. Mestaanwendingsgids'98, technische gegevens en prijzen. Wageningen Pers, Wageningen, The Netherlands, p 47.

Houghton JT, Ding Y, Griggs DJ, Noguer M, van der Linden PJ, Dai X, Maskell K, and Johnson CA (eds.), IPCC Working group. 2001. Climate change 2001: the scientific basis. Cambridge University Press, Cambridge, UK. Available from: http://www.ipcc.ch/

Huijsmans J.F.M., De Mol R.M. 1999. A model for ammonia volatilization after surface application and subsequent incorporation of 
manure on arable land. J. Agr. Eng. Res. 74:73-82.

Huijsmans J.F.M., Hol J.M.G., Hendriks M.M.W.B. 2001. Effect of application technique, manure characteristics, weather and field conditions on ammonia volatilization from manure applied to grassland. Neth. J. Agr. Sci. 49:323-42.

Huijsmans J.F.M., Hol J.M.G., Vermeulen G.D. 2003. Effect of application method, manure characteristics, weather and field conditions on ammonia volatilization from manure applied to arable land. Atmos. Environ. 37:3669-80.

Huijsmans J.F.M., Verwijs B., Rodhe L., Smith K. 2004. Costs of emission-reducing manure application. Bioresource Technol. 93:11-9.

Infascelli R., Faugno S., Pindozzi S., Pelorosso R., Boccia L. 2010. The environmental impact of buffalo manure in areas specialized in mozzarella production, southern Italy. Geospatial Health. 5:131-7.

Infascelli R., Pelorosso R., Boccia L. 2009. Spatial assessment of animal manure spreading and groundwater nitrate pollution, Geospatial Health. 4:27-38.

ISTAT (Italian Institute of Statistics). 2011. Indice dei prezzi al consumo per le rivalutazioni monetarie [In Italian]. Available from: http://www.istat.it/it/archivio/30440

m\&ma Macchine e Motori Agricoli. 2004. Directory of farm machinery [In Italian]. Macchine e Motori Agricoli 90:suppl 11. Available from: http://www.edagricole.it/r_18_dett.asp

McGechan M.B., Wu L. 1998. Environmental and economic implications of some animal slurry management options. J. Agr. Eng. Res. 71: 273-83.

Mueller L., Schindler U., Fausey N.R., Lal R. 2003. Comparison of methods for estimating maximum soil water content for optimum work- ability. Soil Till Res. 72:9-20.

Osei E., Gassman P.W., Hauck L.M., Jones R., Beran L., Dyke P.T., Goss D.W., Flowers J.D., McFarland A.M.S., Saleh A. 2003. Environmental benefits and economic costs of manure incorporation on dairy waste application fields. J. Environ. Manage. 68:1-11.

Peters J., Combs S., Hoskins B., Jarman J., Kovar J., Watson M., Wolf A., Wolf N. 2003. Recommended methods of manure analysis A3769. University of Wisconsin-Madison, Madison, WI, USA. Available from: http://uwlab.soils.wisc.edu/

Prapaspongsa T., Christensen P., Schmidt J.H., Thrane M. 2010. LCA of comprehensive pig manure management incorporating integrated technology systems. J. Clean Prod. 18:1413-22.

Rayment G.E., Higginson F.R. 1992. Australian laboratory handbook of soil and water chemical methods. Inkata Press, Melbourne, Australia.

Redding M.R., Skerman A., Ritchie J., Casey K.D. 2007. How effective are broad-scale nutrient mass balances for determining the sustainability of lot-feed manure application?. Agr. Ecosyst. Environ. 120:166-78.

Rohde L., Etana A. 2005. Performance of slurry injectors compared with band spreading on three Swedish soils with ley. Biosyst. Eng. 92:107-18.

Sommer S.G., Olesen J.E. 2000. Modelling ammonia volatilization from animal slurry applied with trail hoses to cereals. Atmos. Environ. 34:2361-72.

Webb J., Pain B., Bittman S., Morgan J. 2010. The impacts of manure application methods on emissions of ammonia, nitrous oxide and on crop response - A review. Agr. Ecosyst. Environ. 137:39-46. 